\title{
Barriers of the Management Accounting Application: The Case of Vietnamese Public Universities
}

\author{
Submitted 14/01/20, $1^{\text {st }}$ revision 09/02/20, $2^{\text {nd }}$ revision 18/03/20, accepted 27/04/20
}

Oanh Thi Tu LE $E^{l}$, Trang Thi Huyen VU⿱丷 , Phong Thi Thu TRAN ${ }^{3}$

\begin{abstract}
:
Purpose: This study investigated barriers of the management accounting application in Vietnamese public universities. In line with the trend of rapid transformation in higher education, Vietnamese public universities have gradually been given autonomy in their operations, shifting from being managed by the government to operating more independently.

Design/Methodology/Approach: Data for this research were collected through surveying 53 Vietnamese public universities on a 5-point Likert scale, using SPSS software with descriptive statistics, analysis, and comparison to achieve research objectives.

Findings: The research results show that there are barriers to the application of management accounting in Vietnamese public universities: (i) Documents guiding the implementation of management accounting, (ii) Awareness of university managers about the role of management accounting, (iii) Human personnel in charge of management accounting, and (iv) Accounting management software.

Practical Implications: These findings not only help managers to assess the impact of barriers in applying management accounting but also provide solutions for managers to enhance management accounting, contributing to the provision of quality accounting information in Vietnamese public universities.

Originality/Value: The application of management accounting helps public universities better utilize the information for decision making and ensure operational efficiency and quality of training.
\end{abstract}

Keywords: Autonomy, barrier, management accounting application, Vietnamese public universities.

JEL Code: M10, M40, M41.

Paper Type: Research study.

\footnotetext{
${ }^{1}$ University of Labour and Social Affairs, Vietnam, E-mail: oanhletu@gmail.com

${ }^{2}$ ThuyLoi University, Vietnam, E-mail: Trangvth@tlu.edu.vn

${ }^{3}$ Hanoi Open University, Vietnam, E-mail: thuphonghou@gmail.com
} 


\section{Introduction}

Management accounting first appeared in the US in the late nineteenth century, and today it has been developed into a highly applicable economic science in most developed countries. Management accounting is defined as identifying, measuring, analyzing and communicating financial information to managers in order to fulfill the organization's goals (Kaplan and Atkinson, 2007). For universities, management accounting is the collection, processing, analysis and provision of economic and financial information according to management requirements, serving the planning, evaluating, controlling and making economic and financial decisions within the universities. In Vietnam, management accounting was recognized and published in Accounting Law in 2003 (National Assembly, 2003) and Circular No. 53/2006 / TTBTC (Ministry of Finance, 2006). Although management accounting is considered as an effective management tool, it is currently being applied mainly in Vietnamese enterprises.

However, management accounting remains formal and obligatory according to regulations but not really promoting its role as a tool to serve the decision-making of managers at all levels of universities. The information is stereotypical and serves the external reporting purpose such as estimations, reporting the use of funds. Moreover, certain important information for decision-making of universities has not been provided such as the breakeven point regarding the number of students, tuition fees and courses, cost control and evaluation for each department unit. The limitations of current accounting information are major obstacles in improving the effectiveness of management. Based on the above issues, the study was conducted to understand the factors hindering the application of management accounting in public universities in Vietnam as well as conditions for improving the effectiveness of management accounting in universities.

\section{Literature Review}

\subsection{Review of Studies on the Application of Management Accounting}

In the early $19^{\text {th }}$ century, manufacturing enterprises succed in certain achievements in terms of efficiency, thanks to advances in management and decentralization. Achievements in production have laid the foundation for the introduction of modern management accounting. Kaplan and Johnson (1987) concluded that the accounting management system is developed to promote and evaluate the effectiveness of internal processes, not to measure the overall profitability of an organization. New management accounting techniques have been introduced to support budget planning and control activities, ensuring that the diversified activities of various departments are in harmony with the common goals of companies as well as measuring the success of each department and the entire organization. 
There has been much research on the factors affecting the management accounting application which mainly referred to management accounting application in largescale enterprises. Nair and Nian (2017) examined the management accounting practice in Malaysia and pointed out that two factors that have significant influence on management accounting in Malaysia are organizational scale and advanced production technology. Shahzadi, Khan, Toor and Haq (2018) investigated the impact of external and internal factors on the application of management accounting in Pakistan and showed that environmental uncertainty, advanced production technology, just in time accounting practices, total quality management and organizational structure affect all processes and simply change all complex systems in Pakistan industries.

For small and medium-sized enterprises, the application of management accounting and the factors affecting the application of management accounting in these enterprises have received attention from researchers. Nguyen et al. (2019) found that CEO's perception of management accounting has a positive impact on the application of management accounting in small and medium-sized enterprises in Hanoi (Vietnam), while the age of managers has a negative impact on the application of management accounting and competition has the weakest impact. Le et al. (2019) examined 120 Vietnamese enterprises in the fields of manufacturing, trading and services to investigate factors affecting the application of management accounting in enterprises in this field. The results showed that 5 out of 6 factors influence the application of management accounting, including, enterprise size, corporate culture, organizational structure, technology, and human resources. Particularly, corporate culture has the greatest impact on the application of management accounting in these enterprises.

Previous studies also proved that firm size is positively correlated with the application of management accounting. In other words, the smaller the size of the enterprise is, the higher the level of application of management accounting and vice versa. Marisa et al. (2020) conducted the Activity-Based Costing (ABC) system adoption for enterprises in the business of building and selling Internet of Things (IoT) based products. The result shows that cost is a function of the volume of production which does not represent the source of value generation. Using ABC system is more difficult to be satisfied by these companies. Prihastiwi and Sholihin (2018) investigated the factors affecting management accounting practices in SMEs in Indonesia and found that qualifications of internal accountants, participants of managers/owners, and enterprise size have significant influence on the application of management accounting.

A research by Szychta (2018) in Poland was conducted to identify the type of management accounting used in business entities and to identify trends, changes in management accounting methods, and duties of management accounting. It confirmed that the number of companies in Poland which have departments in charge of management accounting had increased steadily. Al-Hawari and Nassar 
(2017) examined factors affecting the application of management accounting in Jordan and found that firm size, firm age and competition directly affect both the costing system and budgeting system. Ahmad and Zabri (2015) investigated factors influencing the adoption of management accounting in medium-sized manufacturing companies in Malaysia and found that firm size, market competition, the commitment of the owners/managers, and advanced technology have significant impact on the application of management accounting. A study of Tahar and Ménacère (2013) examined the role of management accounting application and the factors affecting the application of management accounting in the public sector in developing countries and found that management accounting practices faced challenges including budgeting and budget planning issues, budget control and performance evaluation.

\subsection{Review of Studies on Management Accounting in Public Universities}

There has been not much research on management accounting applications and factors affecting the application of management accounting in the field of public education in general and in public universities in particular. Some previous studies mentioned factors affecting management accounting in public schools, such as (i) guiding documents on management accounting in public units; (ii) the managers' concern about management accounting information; (iii) the role of accountants and supporting tools for providing information.

Upping (2010) examined accounting reforms in public universities in Thailand and pointed out that the majority of Thai public universities were making changes in both financial accounting system and management accounting, they had either been implemented or in the process of implementing Activity-based costing (ABC). The further study of Upping and Oliver (2011) on the factors affecting the changes of management accounting in Thai public universities showed that the majority of Thai public universities were making changes in cost accounting to serve the purpose of planning and controlling costs to overcome the challenges of reducing government budget and increasing autonomy.

Bollecker (2016) studied the application of management accounting in universities in the presence of internal divisions in the context of having many contradictory documents that impose management accounting in public administration. The results showed that the separation of tools and the compromise in the application is explained by the disparities in resource allocation, resource redistribution strategies and factors related to the organization's history, availability of resources and status of administrative staff.

Bollecker (2013) explained the differences in concern in management control in the same organization. While some managers are very interested in the overall management control information, others only pay attention to some relevant information. The study explained the failure of implementing management 
accounting regarding the purpose of using information. Research on management accounting in public universities was conducted by Owino, Munene and Ntayi (2016) to examine the accountability status in public universities in Ugandan. The study found that there existed responsibility accounting systems in public universities in which costs and revenues were accrued and reported from faculty and from faculty to university management, the head of the department has the authority to manage their estimates of budget allocation. However, responsibility accounting which follows the model of decentralization in public universities is not emphasized. The reporting system of the public university is mainly formal, which affects the use of information of the Board of Directors to make decisions.

Another study from Upping and Oliver (2012) investigated the modernization of management accounting application in Thai public universities and proved that the main factors affecting the changing process are the low level of institutional capacity of some Thai universities due to the lack of technology resources and staff with accounting knowledge of the private sector. Research of Kasravi, Ghasemi and Najafizadeh (2017) in Tafresh University of Health Sciences suggested that organizational strategy has a positive impact on management accounting design but has no impact on the use of management accounting, and management accounting design does not affect the use of management accounting. This study also confirmed that all aspects of management accounting have positive impact on financial and organizational efficiency.

\section{Data and Methods}

The research data was collected by distributing questionnaires to the Planning and Finance Department of Vietnamese public universities. The questionnaire was used a 5-point Likert scale and the designed was based on previous research on accounting in universities contacted by Upping and Oliver (2012), Bollecker (2016), and Redenbaugh (2005).

Regarding the characteristics of respondents, a total of 53 people participated in the survey, most respondents were female $(40,75.5 \%)$ and accountants $(46,86.8 \%)$. Regarding working tenure, the majority of respondents had been working for more than 10 years $(27,50.9 \%)$, which is followed by the number of respondents who had been working from 5 to 10 years $(19,35.8 \%)$. Regarding the level of education, the number of postgraduates is higher than the number of university graduates $(40$, $75.5 \%)$.

Regarding the characteristics of surveyed public universities, the number of questionnaires sent was 138, and the number of answers received was 53. Out of 53 surveyed universities, 16 were fully autonomous (30.2\%), 29 were partially autonomous schools (54.7\%) and 8 universities were not autonomous. In terms of the number of years of establishment, most surveyed universities had been established for 50 years or more $(25,47.2 \%)$. The next most common group was 
universities which had been established for between 20 and 50 years (16, 30.2\%). The rest were universities which had been established for less than 20 years.

Regarding location, the majority of universities were located in the North of Vietnam $(30,56.6 \%)$. The number of universities located in the Central and the South of Vietnam was relatively equal (the rates are $20.8 \%$ and $22.6 \%$ respectively). Regarding region, out of 138 public universities in Vietnam, the number of universities in the North accounted for $54 \%$. The number of universities in the Central took up 20\% and the number of universities in the South accounted to $27 \%$ $(\mathrm{Vu}, 2017)$, the distribution rate of the sample of 53 public universities surveyed is equivalent to the overall.

The data collected were processed with SPSS 20 through descriptive statistics, comparing the results between groups of universities based on the degree of autonomy. This study applied statistical methods, analyzing, comparing results to achieve research objectives.

\section{Research Results and Discussion}

\subsection{Barriers of the Management Accounting Application in Vietnamese Public}

The limitations of the application of management accounting in public universities are measured by 4 aspects as follows: (i) there is a lack of documents guiding the implementation of management accounting; (ii) the university management has not paid attention to management accounting information; (iii) there is no specialized accountant in management accounting; (iv) there is no suitable software to support the provision of management accounting information. Descriptive statistics are shown in Table 1.

Table 1. General barriers of the management accounting application

\begin{tabular}{|l|l|l|l|l|l|l|l|}
\hline Content & S1 & S2 & S3 & S4 & S5 & S4\&S5 & Mean \\
\hline $\begin{array}{l}\text { 1. There is a lack of documents } \\
\text { guiding the implementation of } \\
\text { management accounting. }\end{array}$ & $0 \%$ & $10.9 \%$ & $20.0 \%$ & $50.9 \%$ & $18.2 \%$ & $69.1 \%$ & 3.76 \\
\hline $\begin{array}{l}\text { 2. The university management has } \\
\text { not paid attention to management } \\
\text { accounting information }\end{array}$ & $0 \%$ & $32.7 \%$ & $30.9 \%$ & $30.9 \%$ & $5.5 \%$ & $36.4 \%$ & 3.09 \\
\hline $\begin{array}{l}\text { 3. There is no specialized } \\
\text { accountant in management } \\
\text { accounting. }\end{array}$ & $0 \%$ & $18.2 \%$ & $25.5 \%$ & $49.1 \%$ & $7.3 \%$ & $56.4 \%$ & 3.45 \\
\hline $\begin{array}{l}\text { 4. There is no suitable accounting } \\
\text { software to support the provision of } \\
\text { management accounting } \\
\text { information. }\end{array}$ & $0 \%$ & $23.6 \%$ & $18.2 \%$ & $45.5 \%$ & $12.7 \%$ & $58.2 \%$ & 3.47 \\
\hline
\end{tabular}

Note: S1: Strongly Disagree; S5: Strongly Agree.

Source: Compiled from the survey. 
Table 1 shows that the percentage of "strongly agree" and "agree" for "there is a lack of documents guiding the implementation of management accounting" is the highest $(69.1 \%)$. This is followed by "there is no suitable accounting software to support the provision of management accounting information" $(58.2 \%)$ and "there is no specialized accountant in management accounting" (56.4\%). The item which did not receive much agreement was "the university management has not paid attention to management accounting information". A, it received the highest percentage of "disagree" (32.7\%). Regarding the mean values, "the university management has not paid attention to management accounting information" had a mean value of 3.09 which corresponds to a score of "partly agree". The remaining items reached the score of "agree". Particularly, "there is a lack of documents guiding the implementation of management accounting" had the highest mean score (3.76). The remaining items "there is no suitable accounting software to support the provision of management accounting information" and "there is no specialized accountant in management accounting" had similar mean values (3.45 and 3.47). These results are shown in Figure 1.

Figure 1. Barriers of the management accounting application in terms of frequency and mean

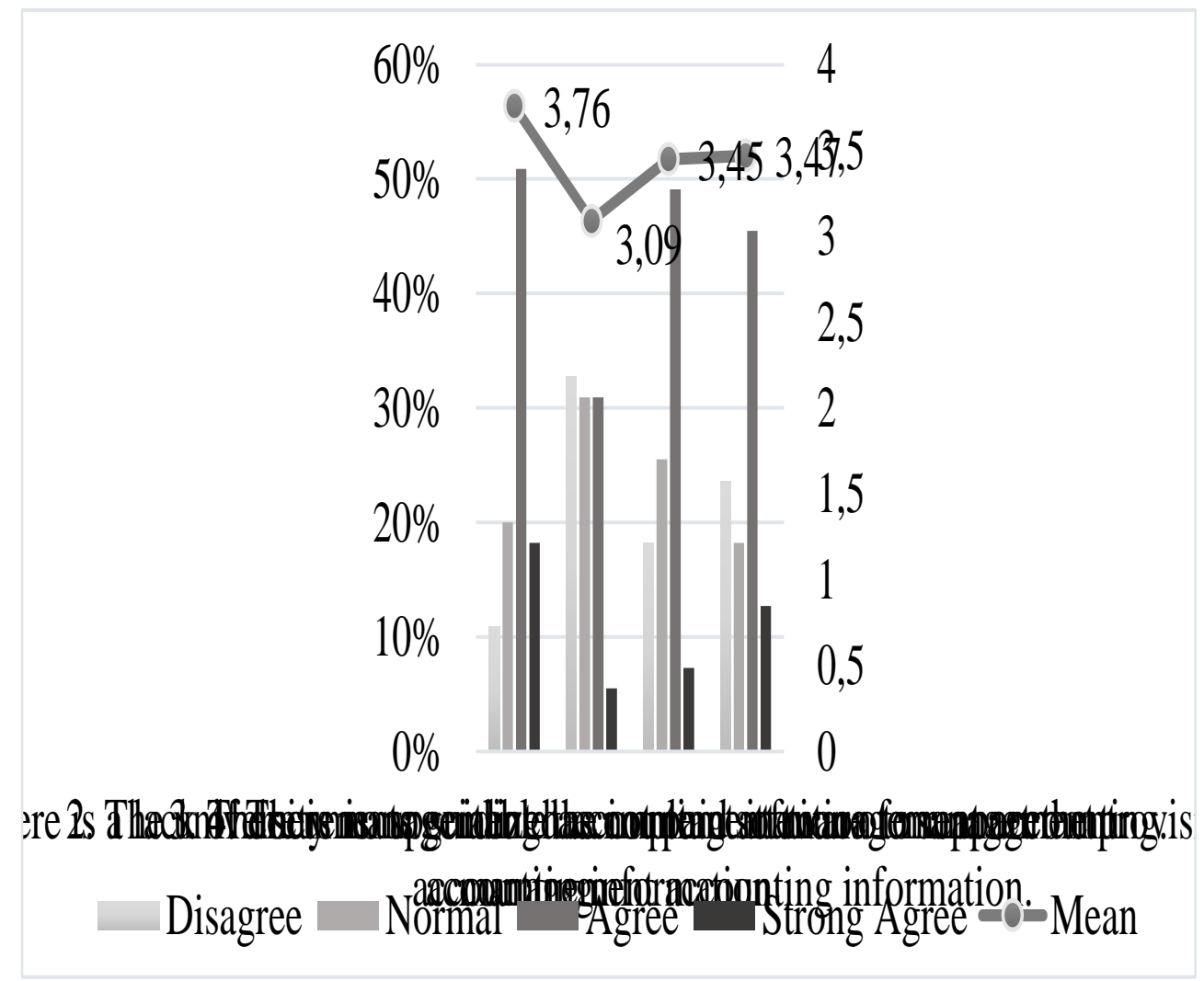




\subsection{Barriers of the Management Accounting Application in Vietnamese Public Universities Regarding the Degree of Autonomy}

Considering whether there is a difference between public universities with different levels of autonomy, Figure 2 shows that the biggest limitation affecting management accounting implementation of all groups of universities is that "there is a lack of documents guiding the implementation of management accounting". Two limitations "there is no suitable accounting software to support the provision of management accounting information" and "there is no specialized accountant in management accounting" had similar mean values among groups (mean values ranging from 3.3 to 3.5). However, there is a difference in the limitation "the university management has not paid attention to management accounting information". Particularly, the group of autonomous universities rated this item with mean values ranging from 2.9 to 3.1 which correspond to a score of "partly agree". The group of non-autonomous universities rated this item higher than autonomous universities with a mean value of 3.5 which corresponds to a score of "agree". In general, the assessments of the totally autonomous universities and partly autonomous universities are similar. Particularly, the mean values of the partially autonomous universities are higher than those of the totally autonomous universities. The group of non-autonomous universities rated the limitation contradictorily with the other two groups of universities.

Figure 2. Barriers of the management accounting application in terms of autonomy

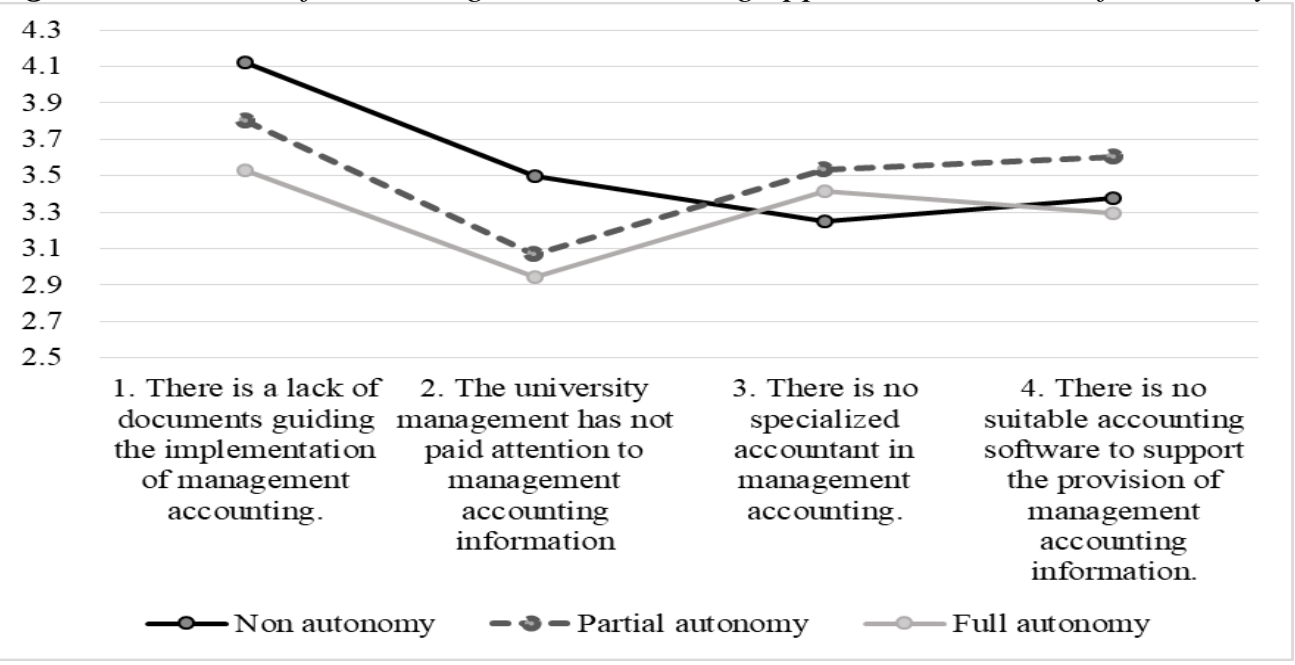

\subsection{Factors Required to Improve the Applications of Management Accounting}

Regarding actions to improve the efficiency of management accounting application in public universities, this study examined the opinions of respondents on the following aspects: (i) the need for the government to provide documents guiding the implementation of management accounting; (ii) raising awareness and knowledge of 
university managers on management accounting; (iii) enhancing awareness and knowledge of accountants regarding management accounting; (iv) equipping accounting software suitable for providing management accounting information. The results are shown in Table 2.

Table 2. Factors need to improve the application of management accounting

\begin{tabular}{|l|l|l|l|l|l|l|l|}
\hline Content & S1 & S2 & S3 & S4 & S5 & S4\&S5 & Mean \\
\hline $\begin{array}{l}\text { 1. The need for the government to } \\
\text { provide the documents guiding the } \\
\text { implementation of management } \\
\text { accounting. }\end{array}$ & $0 \%$ & $0 \%$ & $9.1 \%$ & $69.1 \%$ & $21.8 \%$ & $90.9 \%$ & 4.13 \\
\hline $\begin{array}{l}\text { 2. Raising awareness and knowledge } \\
\text { of university managers on } \\
\text { management accounting. }\end{array}$ & $0 \%$ & $0 \%$ & $12.7 \%$ & $67.3 \%$ & $20.0 \%$ & $87.3 \%$ & 4.07 \\
\hline $\begin{array}{l}\text { 3. Enhancing awareness and } \\
\text { knowledge of accountants regarding } \\
\text { management accounting. }\end{array}$ & $0 \%$ & $0 \%$ & $10.9 \%$ & $61.8 \%$ & $27.3 \%$ & $89.1 \%$ & 4.16 \\
\hline $\begin{array}{l}\text { 4. Equipping accounting software } \\
\text { suitable for providing management } \\
\text { accounting information. }\end{array}$ & $0 \%$ & $0 \%$ & $9.1 \%$ & $58.2 \%$ & $32.7 \%$ & $90.9 \%$ & 4.24 \\
\hline
\end{tabular}

Note: S1: Strongly Disagree; S5: Strongly Agree.

Source: Compiled from the survey.

Table 2 shows that all solutions were highly supported by accountants with the percentage of "strongly agree" and "agree" ranging from $87.3 \%$ to $90.9 \%$. Particularly, the percentages of "equipping accounting software suitable for providing management accounting information" and "the need for the government to provide the documents guiding the implementation of management accounting" were highest. In terms of mean values, all solutions are highly appreciated (mean values ranging from 4.07 to 4.24). "Equipping accounting software suitable for providing management accounting information" had the highest mean value of 4.24 , which corresponds to a score of "strongly agree". Other solutions had relatively high mean values which correspond to a score of "agree". Factors hindering the application of management accounting in Vietnamese public universities are shown in Figure 3.

\subsection{Factors Required to Improve the Application of Management Accounting in Public Universities Regarding the Level of Autonomy}

A comparison was made regarding the actions to implement management accounting between groups of universities according to the degree of autonomy. The results of Figure 4 shows that the non-autonomous universities had the highest and stable mean value of 4.3 , which corresponds to a score of "strongly agree". It was followed by the group of partially autonomous universities with mean values ranging from 4.1 to 4.2. The group of fully autonomous universities had widely fluctuating mean values. "Raising awareness and knowledge of university managers on management accounting" had the lowest mean value of 4.0. "The need for the government to 
provide documents guiding the implementing management accounting" had a mean value of 4.1. The remaining actions of fully autonomous universities regarding accounting software and improving the knowledge of accountants had the highest mean values in 3 groups.

Figure 3. Factors need to improve the application of management accounting in terms of frequency and mean

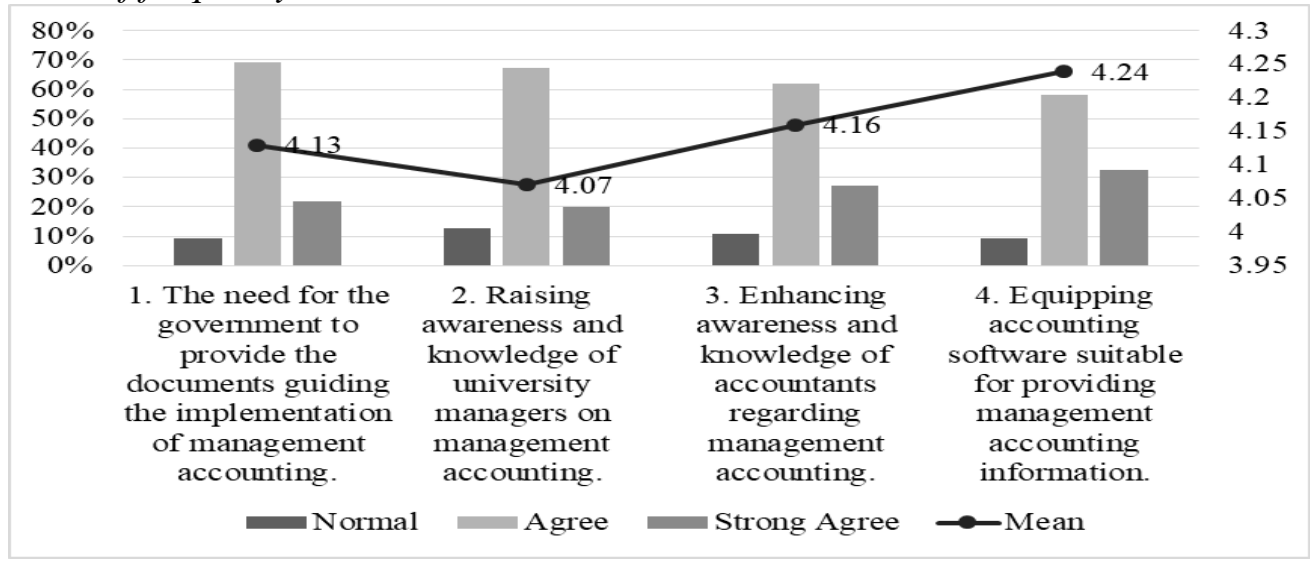

Figure 4. Factors need to improve the application of management accounting in terms of autonomy

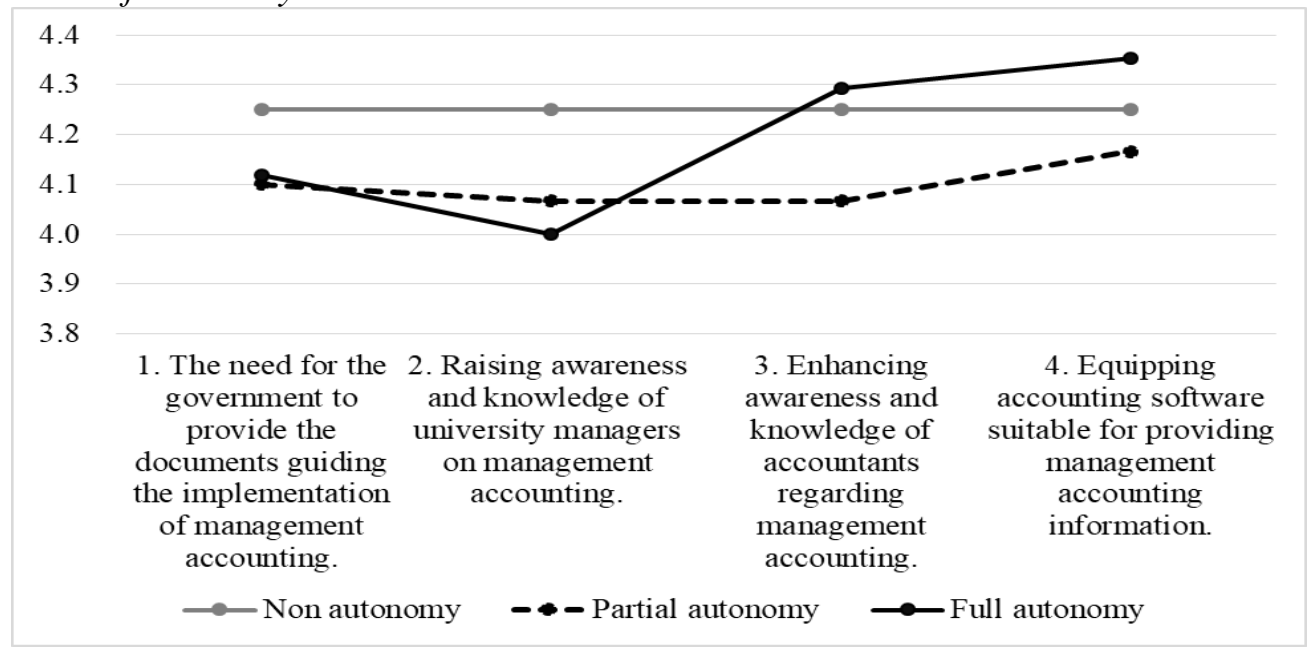

Thus, there is a high consensus on three limitations of applying accounting management in public universities: "there is a lack of documents guiding the implementation of management accounting", "there is no specialized accountant in management accounting", "there is no suitable software to support the provision of management accounting information". Particularly, the limitation that "the 
university management has not paid attention to management accounting information" had lower agreement which shows that the university managers had certain interest in management accounting information when making decisions.

When comparing the groups of universities by the degree of autonomy, the interest of the universities' managers in management accounting information of nonautonomous universities is higher than that of the autonomous universities. This indicates that managers of autonomous universities pay more attention to management accounting information. In terms of actions to implement management accounting, accountants also showed alarming issues. Particularly, there is a lack of documents guiding the implementation of management accounting. In addition, there is no specialized accountant in management accounting. Finally, there is no suitable software to support the provision of management accounting information. These ideas provide an important basis to propose actions to improve the effectiveness of management accounting in Vietnamese public universities.

\section{Conclusion}

The study pointed out that the biggest barrier in the application of management accounting in Vietnamese public universities is the lack of guiding documents on management accounting, lack of suitable accounting software to support management accounting information as well as restrictions on the knowledge and qualifications of accountants. Autonomous and partially autonomous universities face up with more difficulties than fully autonomous one. Accountants also expect to have appropriate accounting software, raise awareness of the management accounting role, enhance knowledge of management accounting for accountants along with completing the guide document system to help management accounting information to be effective in universities.

These results reflect the current situation that public universities are focusing heavily on financial accounting to meet information requirements in accordance with the regulations of the government without realizing the role of management accounting information for managers to make decisions. The knowledge and qualifications of accountants regarding management accounting are also obstacles in providing managers with management accounting information. In particular, accountants lack knowledge of modern management accounting techniques such as activity-based costing, balanced scorecards, and analysis of cost-volume-profit.

On the other hand, the school leadership itself has not paid attention to management accounting information and has not realized the important role and benefits of management accounting information. Although the Ministry of Finance issued Circular 53/2006 / TT-BTC (Ministry of Finance, 2006), it is only general guidance and is therefore not specific to the practice of management accounting and has not been updated according to international trends. The management of universities is more or less bound by the general policy of the government which reduces the 
initiative in making decisions regarding the development of universities according to their visions. In addition, the lack of accounting software to help the accounting departments of universities in providing management accounting information is also a significant obstacle for public universities today.

\section{References:}

AL-Hawari, E., Nassar, M. 2017. The Factors Affecting the Different Management Accounting Practices in Small and Medium Sized Enterprises in Jordan. International Journal of Academic Research in Business and Social Sciences, 7(12), 970-978. DOI: 10.6007/IJARBSS/v7-i12/3727.

Ahmad, K., Zabri, S.M. 2015. Factors explaining the use of management accounting practices in Malaysian medium-sized firms. Journal of Small Business and Enterprise Development, 22(4), 762-781. DOI 10.1108/JSBED-04-2012-0057.

Bollecker, M. 2016. The adoption of management accounting at university: the presence of internal cleavages in a contradictory institutional demands context. Comptabilité Contrôle - Audit, 22, 109-138. DOI 10.3917/cca.222.0109.

Goverment. 2003. Law No. 03/2003 / QH11 of the National Assembly: Accounting Law. Government Electronic Information Public. Retrieved from Details Legal documents: http://vanban.chinhphu.vn/portal/page/portal/chinhphu/hethongvanban?class_id=1\& mode $=$ detail \&document_id=93587.

Kaplan, R.S., Atkinson, A. 2007. Advanced Management Accounting. Prentice Hall International, Inc. ISBN 10: 0132622882 ISBN 13: 9780132622882 . Third edition.

Kaplan, R., Johnson, T. 1987. Relevance Lost: The Rise and Fall of Management Accounting. Boston: Harvard Business School.

Kasravi, A., Ghasemi, M., Najafizadeh, N.A. 2017. The Effect of Management Accounting, Financial Performance and Organizational Performance in Tafresh University. Journal of Internet Banking and Commerce, 22(3), 1-10.

Le, O.T., Bui, N.T., Tran, P.T., Nguyen, H.Q. 2019. Factors affecting the application of management accounting in Vietnamese enterprises. Uncertain Supply Chain Management, 403-422. DOI: 10.5267/j.uscm.2019.10.003.

Ministry of Finance. 2006. Circular No. 53/2006 / TT-BTC Guiding the application of management accounting in enterprises. Database of legal documents of Finance.

Retrieved from Legal documents: https://vbpq.mof.gov.vn/Detail?contentType=LegalDocument $\&$ id=29802\&tab=99.

Nair, S., Nian, Y.S. 2017. Factors Affecting Management Accounting Practices in Malaysia. International Journal of Business and Management, 12(10), 177-184. doi:10.5539/ijbm.v12n10p177.

Nguyen, T.N., Nguyen, H.T., Chu, T.T., Nguyen, D.D., Nguyen, P.T. 2019. Factors affecting the application of management accounting in small and medium enterprises in in Hanoi, Vietnam. Management Science Letters, 9, 2039-2050. DOI: $10.5267 /$ j.msl.2019.7.002.

Owino, P., Munene, J., Ntayi, J. 2016. Does responsibility accounting in public universities matter? Cogent Business \& Management, 3(1), 1-10. https://doi.org/10.1080/23311975.2016.1254838.

Prihastiwi, D.A., Sholihin, M. 2018. Factors Affecting the Use of Management Accounting Practices in Small and Medium Enterprises: Evidence from Indonesia. Journal Dinamika Akuntansi, 10(2), 158-176. 
DOI: http://dx.doi.org/10.15294/jda.v10i1.17307.

Redenbaugh, M. 2005. The use of management accounting tools by chief financial officers of Baccalaureate. College-general and Master's colleges and Universities II. ProQuest Information and Learning Company.

Sanscheza, M., de la Paz Morala. M., Ramoscellib, G. 2020. Activity-based costing in smart and connected products production enterprises. Accounting, 6, 33-50.

DOI: $10.5267 /$ j.ac.2019.6.002.

Shahzadi, S., Khan, R., Toor, M., Haq, A.U. 2018. Impact of external and internal factors on management accounting practices: a study of Pakistan. Asian Journal of Accounting Research, 3(2), 211-223. https://doi.org/10.1108/AJAR-08-2018-0023.

Szychta, A. 2018. Management accounting practices in developing countries since the 1990s: the case of Poland. Zeszyty Teoretyczne achunkowości, 99(155), 119-148. DOI: 10.5604/01.3001.0012.2936.

Tahar, A., Ménacère, K. 2013. Management accounting practices in the public sector of developing countries. African Journal of Accounting, Auditing and Finance, 2(2), 128-145. DOI: 10.1504/AJAAF.2013.057075.

Upping, P. 2010. Accounting reform in the public sector: a case of Thai public universities Phetphrairin Upping. Swinburne University of Technology. Retrieved from Thesis (PhD): http://hdl.handle.net/1959.3/149808.

Upping, P., Oliver, J. 2011. Factors Influencing Management Accounting Change: A case of Thai Public Universities. Indonesian Management and Accounting Research, 10(2), 1-12. DOI: 10.25105/imar.v10i2.1297.

Upping, P., Oliver, J. 2012. Thai public universities: modernisation of accounting practices. Journal of Accounting \& Organizational Change, 8(3), 403-430. https://doi.org/10.1108/18325911211258362.

Vu, T.T. 2017. Financial management in Vietnamese public universities, Monograph. Finance Publishing House, Hanoi, Vietnam. 